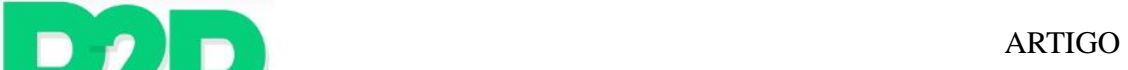

\title{
CAN CAPITALISM REFORM ITSELF AND MOVE TOWARDS A P2P SOCIETY?
}

\section{Jean Lievens}

Graduated in commercial engineering (Solvay) at the VUB (Free University of Brussels). Responsible for the internal communication and coordination of the commercial \& real estate department of the City of Brussels

Graduação em engenharia comercial (Solvay) pela VUB (Universidade Livre de Bruxelas) Responsável pela comunicação interna e pela coordenação do departamento comercial e imobiliário da cidade de Bruxelas

\begin{abstract}
The first Dutch book on P2P "Save the World" by Michel Bauwens had a good reception in Flanders. Even for the critics, the emerging way of 'getting things done' through global cooperation on "what is light" and relocalisation of "what is heavy" is making a lot of sense and is indeed the way to go. In this article, we examine two criticisms of the book: the feasibility of an unconditional basic income within the present system and the possibility to move gradually to a P2P society without "overthrowing" capitalism. Apart from the "low road" to peer-to-peer (after an economic collapse) and "the high road to peer-to-peer" (through neoKeynesianism) a third way could open up, based on a reformed partner state facilitating peer production. Our conclusion is that under the present circumstances, with exponentially growing bottom-up initiatives, open source alternatives and the Internet as a new means of production, value creation and distribution, past failed experiences of 'socialism in one country' could today have more chances of succeeding on condition that a progressive government arms itself with a commons transitional plan. Such a transitional government would undoubtedly face many difficulties, but it would at least open the horizon for a better future. And it would certainly enjoy a wave of solidarity throughout the world.
\end{abstract}

Keywords

Capitalism. Peer-to-peer. Open Source. Internet.

\section{PODE O CAPITALISMO REFORMAR A SI PRÓPRIO E SE ENCAMINHAR PARA UMA SOCIEDADE P2P?}

\section{Resumo}

O primeiro livro holandês sobre P2P "Save the World" de Michel Bauwens teve boa recepção em Flandres. Mesmo para os críticos, a nova forma de "conseguir fazer as coisas" através da cooperação sobre "o que é leve” e a relocalização de "o que é pesado" faz muito sentido e é, sem dúvida, o caminho a seguir. Neste artigo, analisamos duas críticas feitas ao livro: a viabilidade de renda básica incondicional dentro do sistema presente e a possibilidade de mudar gradualmente para uma sociedade P2P sem "derrubar" o Capitalismo. Além de uma "low road to peer-to-peer" (depois de um colapso econômico) e "the high road to peer-to-peer" (através do neo-keynesianismo) uma terceira via poderia ser aberta, baseada num estado parceiro reformado que facilitasse a produção do tipo "peer". Concluímos assim que nas circunstâncias presentes, com iniciativas "bottom-up" crescendo exponencialmente, alternativas de código aberto e da Internet como novo meio de produção, criação e distribuição de valores, experiências falidas de 'socialismo em um só país' no passado poderiam agora ter mais chances de sucesso sob a condição de que um governo progressista se arme com um plano de transição dos comuns. Tal governo de transição poderia sem dúvida enfrentar muitas 


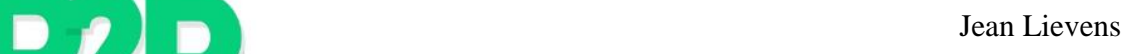

dificuldades, mas pelo menos abriria os horizontes para um futuro melhor. E certamente gozaria de uma onda de solidariedade no mundo inteiro.

\section{Palavras-chave}

Capitalismo. P2P. Código aberto. Internet.

\section{INTRODUCTION}

The first Dutch book on P2P "Save the World" by Michel Bauwens had a good reception in Flanders, but there was also some criticism. We examine two of them: the feasibility of an unconditional basic income and the possibility to move gradually to a P2P society without "overthrowing" capitalism. The Greek experience learns us a lot about the need to, under the present social and political circumstance, carry out a transition process between the "high road" to P2P, and the "low road to P2P (P2P FOUNDATION, 2015).

The first edition of the Dutch book on peer-to-peer "De Wereld Redden" (BAUWENS; LIEVENS, 2013) (full English title: "Save The World - With Peer to Peer to a Post Capitalist Society") was published almost two years ago. This book was based on twelve in-depth interviews that I had with Michel Bauwens in January and February 2013. After two reprints and a successful translation into French (print run 20.000) (BAUWENS; LIEVENS, 2015), we are preparing a new edition for an English speaking audience. The new book will explain the basic ideas of peer to peer and stressing the importance of peer production as a transformative force towards a new stage in human civilization, but will also dig deeper into P2P theory based on new insights and practices.

\section{SAVE THE WORLD}

The basic idea presented in "Save the World" is quite simple, but at the same time very profound: peer-to-peer carries the seeds of a new societal model in which commons based peer production will move to the core of a new post-capitalist economic order. In this future society, capitalist production will to a large extent be replaced by peer production, private (capitalism) or state (socialism) ownership of the means of production by peer property and traditional hierarchical governance of organisations by peer governance. These developments will affect every single aspect of human life and thought, including 
politics, philosophy and even spirituality. Finally, this future society is not the product of wishful thinking or rooted in some utopia, but based on emerging practices made possible by network technology, a subject that has been widely covered in former editions of this magazine. This transition however, will not necessarily be automatic.

Oddly enough and contrary to our expectations, the rather self-indulgent title of the book (Save the World) and its core idea, summed up in the baseline "With P2P Towards a Post-capitalist Society" received hardly any criticism. This suggests a broad consensus (at least amongst the readers and reviewers) that the world indeed needs saving, but more importantly, that this emerging way of 'getting things done' through global cooperation on "what is light" (immaterial commons of code, knowledge and design) and re-localisation of "what is heavy" (material production) is making a lot of sense and is indeed the way to go.

Michel Bauwens puts forward different scenarios and develops political and programmatic proposals to make the phase transition towards $\mathrm{P} 2 \mathrm{p}$ as smooth and efficient as possible. The P2P-model is based on a hyper productive civil society contributing voluntary and passionately to the production of immaterial commons of software, design and knowledge. Around this core, an entrepreneurial coalition of corporations contributing to these "collaborative commons", are still competing and using the market to allocate the scarce added value products and services they produce on top of these commons. Instead of cooperation on a corporate level within competition, we get competition within collaboration on a commons level. The commons become the centre, the market moves to the periphery.

These model is rooted in emerging practices as more and more citizens are taking their own initiatives, are mutualising knowledge and physical infrastructures (the real sharing economy) and are contributing to all sorts of commons. But more broadly and

fundamentally, people are especially looking for practical solutions for the problems of our time: the economic crisis, climate change, raising inequality and insecurity, soil depletion, health problems due to cheap and unhealthy food, etcetera.

\section{POLITICAL IMPACT P2P BOOK IN FLANDERS}

The P2P-book was a modest success in sales, but had a significant and still growing cultural and political impact in Flanders. After the release Michel Bauwens not 


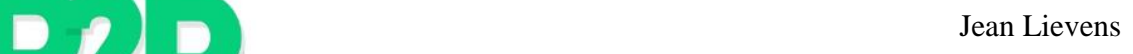

only received a lot of media attention, but the book was also mentioned by mainstream politicians such as the former Belgian Prime Minister Jean-Luc Dehaene (Christian Democrat), who declared, just a couple of weeks before his unexpected death, in an interview with the progressive newspaper 'De Morgen' the following:

\begin{abstract}
Maybe the solutions are outside politics. This occurred to me when I was reading the book "'Save the World" by the Belgian philosopher Michel Bauwens, momentarily one of the 100 most prominent thinkers in the world. He doesn't develop a theory, but his ideas are based on an existing practice called peer to peer. He sees the emergence of new groups through the Internet, outside traditional circuits. Wikipedia is a powerful example. It's the result of contributions of people who have no profit motive.

On the local level, we will see more and more sharing, group purchases, group production. New groups will develop within society playing a similar role as the trade unions, cooperatives and mutual insurance companies within industrial society. And build new things out of this role. You can call it a new form of community building, which is not commercially steered, although it can be commercially active. A system to which everybody in the world can contribute... (DE MORGEN, 2014).
\end{abstract}

Since this interview, different leading politicians and political parties invited Michel Bauwens to speak at workshops or as a keynote speaker at internal and public meetings. With the exception of the conservative Flemish nationalists (the biggest party in Flanders) and the extreme right Vlaams Belang, all the parties in Flanders showed more or less a genuine interest, from the small Pirate Party over the Greens to the Social Democrats and the Christian Democrats, the second main party. The book received also a quite positive review in "Liberales", a publication of a think tank of the liberal party.

This positive reception reflects the potential of one of the basic political proposals presented in the book: under cognitive capitalism and a knowledge-based economy, which is more and more dominated by networks, a new progressive political majority must be constructed around the commons, not purely on labour as was the case in the past.

A first very important breakthrough has been achieved very recently in the city of Ghent, which is already presenting itself as a 'sharing city'. Michel Bauwens of the P2P Foundation was asked to develop a commons transition plan for Ghent in order to become a "commons city". This plan will be mainly inspired by the FLOK Society project (BUEN CONOCER, 2015) that was launched in Ecuador last year. 


\section{MAIN CRITICISMS}

Nevertheless, despite the good reviews, the book was also criticised. The main criticism however concerned issues that were not or hardly mentioned in the book, such as the introduction of an unconditional basic income. Another issue, mainly put forward by the (far) left, concerned the nature of the transition process: will it be smooth, gradual and peaceful, or will it be painful, abrupt and violent?

Having said that, the core ideas of the book are often misunderstood. Even after reading, a lot of people still don't seem to differentiate between P2P marketplaces and peer production of commons, despite the graphical overview, represented by a quadrant around two axes: a vertical axe moving down from centralised P2P systems to distributed P2P systems, and from a global level towards a local level, and a horizontal axe moving from for-profit on the left to for-benefit to the right (BAUWENS, 2013). Many consider Über and Airbnb as prominent examples of the sharing economy, although these companies are just a new form of capitalism, with the platform standing between supply and demand, taking an ever-bigger part of the revenue and transforming protected workers into precarious freelancers.

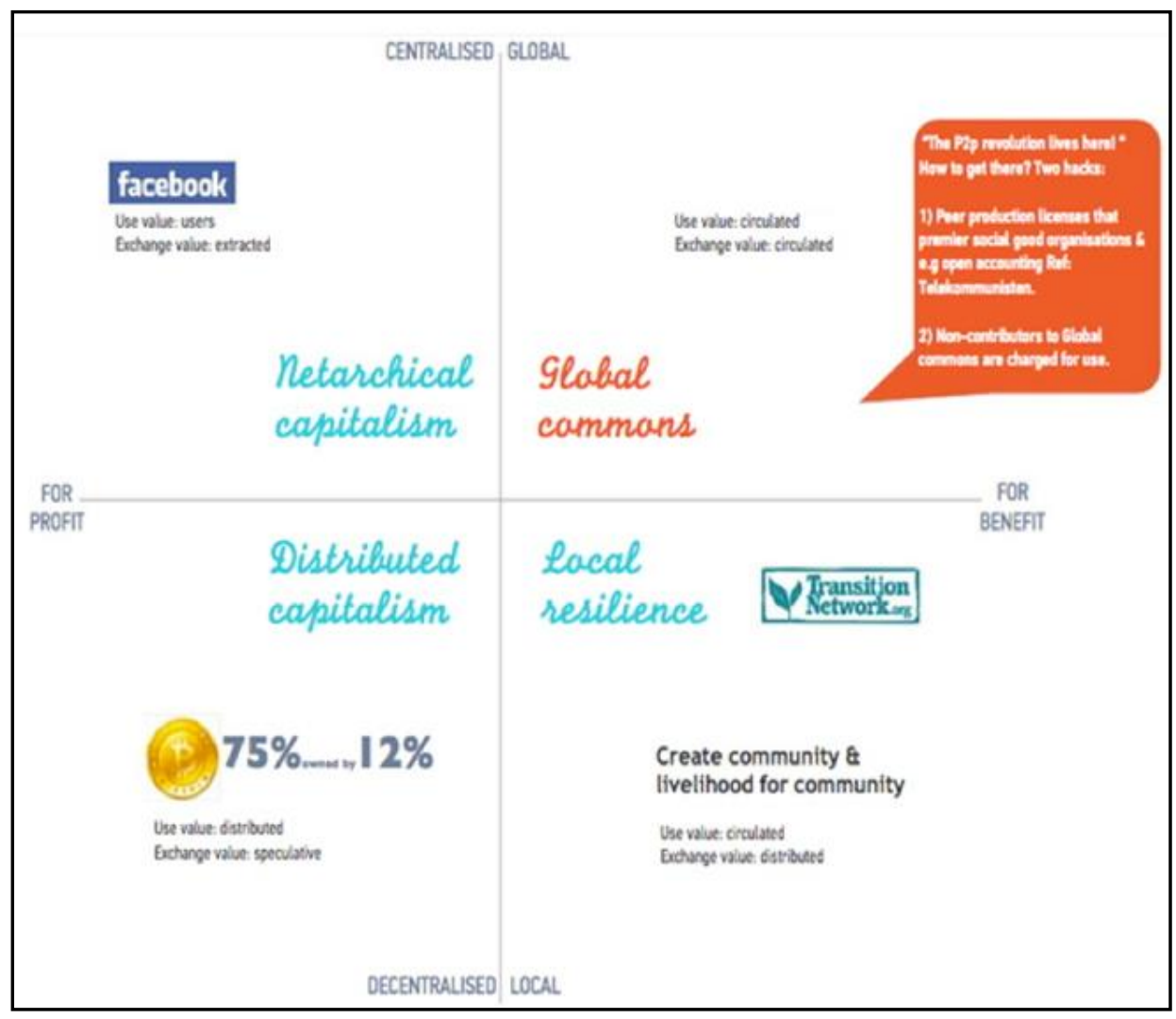




\section{D Iean Lievens}

Apart for those misunderstandings I would like to go into more detail on two main criticism mentioned above, that are also interlinked. Basically, they have a lot to do with two transitional scenarios, described by Michel Bauwens as "the high road to P2P" and the "low road to P2P" The Global Economic System 1). But let us take first a closer look to the unconditional basic income.

\section{UNCONDITIONAL BASIC INCOME}

The idea of providing every citizen with an unconditional basic income would without any doubt significantly stimulate peer production, as citizens would not be dependent on a job to earn their living. Most of commoners are indeed not paid for their contributions to the commons so they need to earn an income in the 'old' economy, by working for a private company, for the government or as a freelancer. Small scale experiences with an unconditional basic income showed very positive results, but how realistic is introducing this on a national level?

A documentary broadcasted on Flemish television (Panorama) showed that an unconditional basic income of 1500 euro per (adult) citizen would be entirely possible. Here's a detailed overview of how this basic income would be financed:

\section{Cost basic Income:}

- 1500 euro/month for each adult above 18 years of age: 157.6 billion

- 200 euro/month for minors under 18: 5 billion

- Personal insurances: 19 billion

- Capital insurances: 4.8 billion

- TOTAL COST: 187.4 billion.

\section{Savings}

- No more pensions: 41,2 billion

- No more unemployment benefits: 11,2 billion

- No more child benefits: 6.4 billion

- No more other social grants: 11,9 billion

- TOTAL SAVINGS: 80,7 billion

\section{Balance: $187.4-70.7=116.7$ billion}




\section{Rationalising Public Sector:}

Less administration (controls), logistics, subsidies etc. $=25.5$ billion

Balance: $116.7-25.5=91.2$ billion.

How to finance this 91.2 billion deficit?

\section{Extra income:}

- Average increase VAT to 25\%: 16 billion

- Augmentation of registration fees to 25\%: 5.3 billion

- Property tax of 25\%: 29.2 billion

- Personal income tax reform: 22.9 billion

- Corporate tax reform: 4.2 billion

- Tax on real estate reform: 2.8 billion

- $50 \%$ recovery on social and fiscal fraud: 12 billion

Balance: $91.2-95.4$ billion $=4.2$ billion profit

\section{REALISTIC OR UNREALISTIC?}

These calculations show that Belgian society is indeed rich enough to give everyone a decent income, but they don't show how this can be carried out in practice. In this model, 91.2 billion extra income is needed, mainly by extra taxes (on VAT and property). But why would such a tremendous tax shift and/or a tax reform that put more burdens on the rich be successful in the context of the introduction of an unconditional basic income? Not even a fraction of that extra needed money can be found today to improve the present welfare system. The slogan "take the money where it is" is simpler said than done.

Another problem with this very generous proposal is that it would divide the producing classes between all those who would be better off and a lot of others who would lose a lot. Let's take pensions. The average pension in Belgium is well under 1500 euro, but the average pension of public servants for instance is more than 2000 euro. In this proposal, pensions would stop to exist all together (saving 44 billion). They would be replaced by a basic income of 1.500 euro. This would of course be unacceptable for all pensioners getting more than that amount. And although it is true that the huge army of civil servants managing and controlling the social security system costs loads of money, simply laying 


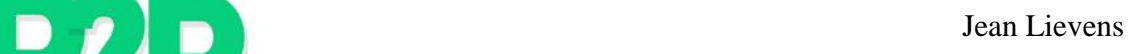

them off because they have what David Graeber calls "bullshit jobs" (GRAEBER, 2015) would provoke very heavy resistance. You could argue that these civil servants should be re-orientated towards useful ans social necessary jobs, but then the bill wouldn't add up anymore (25.5 billion savings in administration costs would be replaced by other expenses).

Off course, an unconditional basic income would be great for the precariat, freelancers who are not covered by the social security system based on wage labour (and for whom private insurance is too expensive), young people who leave school, don't find a job and don't receive any allowance, the unemployed in general (with the exception of those who receive more than 1500 Euros in the first months of unemployment), and, last but not least, the hundred of thousands of workers earning the minimum wage which is less than 1500 euro. In fact, with the introduction of an unconditional basic income, everyone would enjoy a wage increase of 1500 euro! For a lot of people that would mean a doubling of their wage. Furthermore, unconditional means that also well-off people including the 94500 Belgian dollar millionaires (BELGIË, 2015) would receive a state allowance of 1500 euro a month, which would undoubtedly be questioned among the population.

And finally, who would get it? The basic income couldn't be limited to people carrying the Belgian nationality because this would be in conflict with the European legislation. To give it to everyone living on Belgian soil is impossible in the context of migration. Reality is more complex than a simple budget calculation. A more realistic alternative therefore would be the introduction of a transitional income for commoners. This could be partially financed by unemployment benefits and present budgets spend on controlling the unemployed to ensure they are looking for a job and forcing them to follow training schemes to prepare for jobs that don't exist.

\section{POWER SHIFT}

But let's take this idea of an unconditional basic income a little bit further. The capitalist system is based on wage labour: people sell their labour to make a living. The social welfare system has blurred this capitalist logic somewhat, but the core idea remains that wage labour is the norm, and social benefits are nothing more than insurance money against unemployment, sickness, disablement or old age. In addition, social welfare in 
Belgium at least is financed practically exclusively through taxes (called contributions) on labour. So in reality, social benefits are a part of unpaid wages, needed for insurance. Therefore cuts in benefits are in reality wage cuts.

As people contributing to a commons are generally not paid and need other resources for their livelihood, an unconditional basic income would undoubtedly stimulate p2p enormously. So there is no question that an unconditional basic income would mark in reality the end of wage labour, in other words, the end of capitalism. Then the question arises: if "we" would have the power to introduce a generous unconditional basic income, wouldn't we have the power to reform society much more fundamentally? Or is it possible to enter a new growth cycle of capitalism, based on neo-Keynesian politics and positive social and ecological reforms?

\section{THE IMPOTENCE TOWARDS CLIMATE CHANGE}

As I stated in the beginning, the uncontroversial character of the title of the book suggests a growing consciousness that the capitalist system as it is today is at a dead end. This decaying system is not only destroying the planet, it increases inequality to a pre- $20^{\text {th }}$ century level, as shown by Thomas Piketty in Capital (PIKETTY, 2014). In addition, the system does not seem to be able to carry out any positive reforms anymore, neither social, neither ecological.

Take climate change. Multiple studies published in peer-reviewed scientific journals show that at least 97 percent of actively publishing climate scientists agree: climate-warming trends over the past century are very likely due to human activities. In addition, most of the leading scientific organizations worldwide have issued public statements endorsing this position (NASA..., 2015). Already 27 years ago 99\% of NASA was convinced that the burning of fossil fuels causes rising global temperatures. But in January this year, although the US Senate voted virtually unanimously that climate change is occurring and not, as some Republicans have said, a hoax -it defeated two measures attributing its causes to human activity (US...,2015). Despite all the alarming reports on the consequences of climate change, nothing substantial has been done so far.

Compare the impotence towards climate change with the problem of ozone holes that has been more or less solved by collective global measures taken more than 25 years 


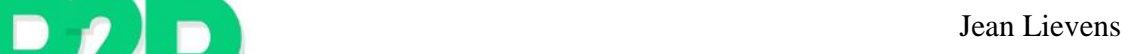

ago. Since the Montreal Protocol agreement in 1987, the emissions of damaging chemicals have been in decline, as ozone-friendly alternative chemicals have come into common usage. Nasa reported in a new study that the ozone holes, which were once arguably the highest profile environmental issue around, would be smaller than 8 million square miles within the next three decades. The evidence now suggests that the hole -currently 12 million square miles- will be fully recovered by the end of the 21 st century (RUNDLE, 2015).

\section{NO MORE SOCIAL REFORMS IN THE WEST}

The incapacity to carry out positive social reforms has been demonstrated over and over again in the last three decades of "counter-reforms" in Western Europe and the USA, but was even more painfully illustrated by the humanitarian crisis in Greece. Despite more than 20 general strikes, the Occupy movement of Syntagma Square and the tremendous electoral victory of Syriza (combined with the near collapse of all main political parties and the rise of the fascist Golden Dawn), the new Syriza led government was forced to swallow a humiliating austerity program by the Troika (European Commission, ECB and IMF). Although bullying and forcing the left wing Greek government to surrender in order to "encourage the others" is undoubtedly an important factor in the policy of the EU and the Troika, we cannot ignore objective capitalist interests behind the latest Greek austerity deal. A simple Grexit in itself wouldn't solve the problem, as Marxist economist Michael Robert explains:

The Keynesians say the way forward is through Grexit and so now do many Austerians. Both see Grexit as a solution to save Greek capitalism. The Keynesians reckon it will 'free' Greek capitalism from austerity. The Austerians reckon it will 'free' the Euro leaders from the wasted funding of a failing capitalist economy. But neither side is right if the profitability of capital does not recover in Greece and in Europe. (ROBERT, 2015)

TINA (there is no alternative) as a perverted version of Fukuyama's "End of History" is pushing countries like Greece over the cliff. This makes the scenario of a high road to $\mathrm{P} 2 \mathrm{P}$, based on neo-Keynesian policies and wealth redistribution in the context of national states unlikely. The traditional left is still exclusively based on the working class, which for more than 30 years has been on the defensive, due to both subjective (a 
leadership that capitulated completely for neoliberal policies), and objective reasons (the decline of large scale industry in the West, hence the numeric decline of the working class). Traditional left wing politics of social reforms financed by taxes and wealth redistribution don't seem to work anymore. That brings us to the classical labour theory of value.

\section{LABOUR THEORY OF VALUE}

According to this theory, first developed by David Ricardo and further elaborated by Karl Marx, human labour is the only source of value creation. That does not mean that water, air and other indispensable 'goods' provided by nature have no value, but as they are abundant and not a product of human labour, they cannot be marketed, although capitalism tries to do exactly that. According to Peter Brabeck-Letmathe, former CEO of Nestlé, the largest food producer in the world, corporations should own every drop of water on the planet and people should pay for it (SAMSON, 2013).

In the industrial phase of capitalism, workers (wage earners) constituted a very large part of the population. The welfare state, a by-product of their struggles, was based on the redistribution of wealth mainly created in industry. In Belgium, one of the few countries where the welfare state -although under attack- is still quite strong, social security is nearly completely financed by labour-based contributions (taxes). The corporate world consider labour costs much too high and pushes the present right wing government to cut more and more in social benefits and carry out a "tax shift" in order to make labour cheaper and business more competitive. On July 23 the Belgian government decided a tax shift of 7,2 billion euro to lower corporate taxes from 33 to $25 \%$, mainly by cutting social benefits.

But if it's true that human labour is the only source of value creation, what about the contributions to commons of code, knowledge and design? This sort of labour obviously creates value, but this value cannot be marketed because the end product is free available for everyone. Under the present system, this leads to two major problems: the contributors cannot live from their contributions, and the commons they produce are used as free raw materials by private business operating in the market. Take the example of open source software. The software is free, but the added value of customisation, adaptation, education etc. is indeed marketed. 


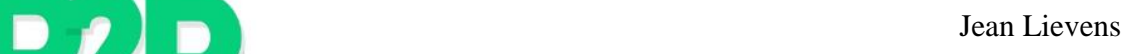

Just as cheap oil, these free common resources give capitalism a new breathing space, but create at the same time new contradictions. Unpaid labour doesn't fuel the consumer market, quite the contrary. Companies can produce cheaper goods, but if at least a part of the created value is not returned to the value creators, there will be nobody to buy the stuff. The same is true for the business model of "platform capitalism" or netartichal capitalism (the hierarchy of the network: peer-to-peer at the bottom, centralised control and $100 \%$ monetisation at the top). Take the business model of Google or Facebook. Income is generated through advertising and the selling user information to corporations (and even governments). In the long run, this business model is not sustainable because it provokes a value crisis. That's probably the reason why Google is moving to more traditional ways of making money, such as investing in self-driving cars and hardware devices. In addition, cognitive capitalism faces more and more problems it fails to resolve: depleted resources, shrinking markets, social and financial instability...

\section{THE HIGH ROAD TO P2P: WHAT ABOUT NE-KEYNESIANISM?}

Let's return to the different scenarios for society to move beyond capitalism. The first scenario, the "high road" to P2P, is quite similar to the ideas developed by Jeremy Rifkin in his latest books "The Third Industrial Revolution" (RIFKIN, 2013) and especially “The Zero Marginal Cost Society" (RIFKIN, 2014). Rifkin's thesis is that within 30 years or so, commons based peer production will be at the core of our economy. Capitalism will continue to exist, but as an auxiliary system, pushed to the periphery. But to get there, massive investments are needed to build the necessary infrastructures for this new Internet of communication, energy and logistics, enabling and facilitating common based peer production. The present Internet as a communication network should indeed be expanded globally and completed by an energy Internet and a logistic Internet.

This presupposes massive public investments that would create millions of traditional jobs, while at the same time, as information technology is eliminating tens of millions of jobs in manufacturing, agricultural and service sectors. New jobs must also be created in the third sector, voluntary and community-based service organisations. According to Rifkin these new jobs should be created with government support to rebuild neighbourhoods and provide social services (RIFKIN, 1996). To finance this last enterprise, 
Rifkin advocates scaling down the military budget, enacting a value added tax on nonessential goods and services and redirecting federal and state funds to provide a "social wage" in lieu of welfare payments to third-sector workers.

Rifkin made these last proposals 20 years ago in his book "The End of Work". But to finance the infrastructures needed for an economy based on the collaborative commons, far bigger budgets are required. So the question arises: where will the money come from? The private sector will only invest if these investments lead to higher profits, but it is doubtful that traditional multinationals will pay for infrastructures that in the end would lead to their downfall. After all in the end, it would lead to a zero marginal cost society in which profit making would be a thing from the past. On the other hand, the new "netarchical" (or platform) capitalists like Facebook (drones) and Google (balloons) do invest in P2P infrastructures on a global scale because their business model is based on it (STONE, 2015).

If on the other hand the already heavy indebted national states have to do the job, it is difficult to see where they will get the money from: by "taxing the rich", by massive deficit spending or by both? Even under the Democratic presidency of Obama, US public investment fell to the lowest level since the Second World War, as reported in the Financial Times (HARDING; MCGREGOR; MULLER, 2013):

Gross capital investment by the public sector has dropped to just 3.6 per cent of US output compared with a post-war average of 5 per cent, according to figures compiled by the Financial Times, as austerity bites in the world's largest economy.

So under the present political circumstances, it seems excluded that governments would engage in such neo-Keynesian policies. History shows that the managerial and owner classes only make these kinds of concessions when their own survival is at risk, as was the case after the Second World War. Afraid for the "communist threat", they introduced the Marshall Plan and the welfare state. Today, in the absence of an alternative economic system, there is no political motivation to introduce a large public investment program to build the infrastructures for a new economy based on the collaborative commons seems unlikely, even if such a scenario would be highly preferable. But what about the economic motivation and feasibility? 


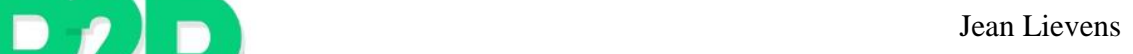

The problem is that the financialisation of the world economy has created incredibly huge amounts of fictitious capital, which are easier destroyed than taxed. As David Graeber and others explain, money is created out of thin air by private banks every time a loan is made, on condition that the borrower is (or is not as the subprime crisis has shown) creditworthy, that is, capable of paying the loan back with interests. The result is a continuous cycle of financial bubbles and inevitable bursts, mostly triggered by "external" events: a bank going bust, a rise in energy prices above a certain level (Rifkin puts forward the figure of 147 \$ for a barrel of oil) and today after the Greek experience we can add any attempt by a left wing government to radically change policy. This would undoubtedly also be "punished" by the financial markets.

\title{
12 THE LOW ROAD TO P2P
}

So under the current circumstances, the most likely transition towards $\mathrm{P} 2 \mathrm{P}$ is the "low road". Therefore the best way for moving forward at present is to build our own peerto-peer alternatives here and now, including local en digital currencies, and make our networks and solidarity mechanisms stronger. Michel Bauwens already expressed this view in 2010, in the aftermath of the financial crisis:

\begin{abstract}
What seems to be happening is that mobilization is increasingly happening indeed, and also the quite rapid spread of open and sharing infrastructures, BUT, there is no longer anyone to talk to. The enlightened part of the nation states either do not exist or are two weak, and the global market forces are intent to break what remains of their independence, and hence, what they can do and signify for their own peoples. They're is simply nobody there anymore, the system has exhausted its capabilities to rectify outside of the narrow interests of the predatory financial class (BAUWENS, 2015).
\end{abstract}

Also in 2010, John Robb, author, entrepreneur, inventor and a former USAF pilot in special operations wrote: (ROBB, 2010)

For those that think that this will bring about a surge of peaceful economic vigour, you will be wrong. It will fragment society and lead to perpetual stagnation/depression, endemic violence/corruption, and squalor. For absent any moral basis (a social compact), stability, or (widely shared) prosperity: new sources of order will emerge to fill the gap left by the hollowing out of the nationstate. These new sources of order will be first seen in the rise of the criminal entrepreneur, whether they be the be suited corporate gangster or the gang tattooed thug. For in the world of hollow states (without a morality that limits 
behaviour) and limitless connectivity to the global economic system, these criminal entrepreneurs quickly become dominant, violently coercing or corrupting everyone in the path to their enrichment.

Building the alternatives in a low road scenario shouldn't however be all that dramatic, as John Rob already stated in 2009:

In either case, system recovery could be catalyzed and the damage largely mitigated, if our global system was scale invariant. Basically, this means that if we had communities that could produce at the local level many of the essential products and services currently produced at the global level, handling disconnection or buffering turbulence would be of little consequence (also, it would be much easier for us to find ways of protecting or making redundant the products/services that ONLY could be produced at the global level). Fortunately, particularly given the substantial uptick in dynamic instability at the global level, we are seeing movement towards scale invariant resilient communities. These communities can and would be able to operate autonomously regardless of availability, pricing, or quality of external goods/services for extended periods of time. Unfortunately, this movement may not spread quickly enough to provide any meaningful support to those communities that are utterly dependent on the smooth functioning of the global system. (ROBB, 2009)

\section{COMMONS TRANSITION PLAN ON A NATIONAL LEVEL}

John Rob was talking about local communities, about local resilience. But what is local in a globalised world? Is it communal, regional, or even national? We could argue that in the case of Greece, a plan B, based on the introduction of a "local" (in this case national) currency protecting and stimulating the local economy (and keeping the euro for international payments), and a governmental commons transition plan to turn the Greek state into a facilitator for commons based peer production, could well be a viable alternative to the present situation in which the country has in effect been turned into a European protectorate, stripped from every shred of sovereignty and democracy.

Europe and the West would of course meet such a move with the greatest hostility. It wouldn't be the first time that a country wanting to reform is pushed much further than originally planned because of the reaction of the West. Remember Cuba. But all nations that introduced socialism in the 20th century were characterised by bureaucratic deformations and a lack of democratic involvement right from the early beginning. This democratic deficit and the bureaucratic planning of the economy led ultimately to the failure of the "communist" or "socialist" experiments in the 20th century. It was also the 


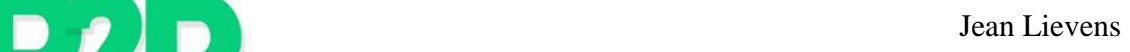

reason that the new (mainly Latin American) progressive regimes of the 21 st century didn't go "all the way".

But even during some of the socialist experiences in the past, attempts were made to improve the planned economy using cybernetics, as shown in the semi-fictional book Red Plenty by Francis Spufford (SPUFFORD; PLENTY, 2011). In this book, Spufford explains that under Nikita Khrushchev, plans were made to use a sort of "internet avant la lettre" to make the planned economy work, not only for the production of steel and concrete, but also for the production of sophisticated production goods. As the Guardian reports: (SPUFFORD, 2010)

But during the Soviet moment there was a serious attempt to apply the intellectual resources of the educated country the Bolsheviks had kicked and bludgeoned into being. All of the perversities in the Soviet economy that I've described above are the classic consequences of running a system without the flow of information provided by market exchange; and it was clear at the beginning of the 60 s that for the system to move on up to the plenty promised so insanely for 1980, there would have to be informational fixes for each deficiency. Hence the emphasis on cybernetics, which had gone in a handful of years from being condemned as a "bourgeois pseudo-science" to being an official panacea.

The USSR's pioneering computer scientists were heavily involved, and so was the authentic genius Leonid Kantorovich, nearest Soviet counterpart to John Von Neumann and later to be the only ever Soviet winner of the Nobel Prize for economics. Their thinking drew on the uncorrupted traditions of Soviet mathematics. While parts of it merely smuggled elements of rational pricing into the Soviet context, other parts were truly directed at outdoing market processes. The effort failed, of course, for reasons which are an irony-laminated comedy in themselves. The sumps of the command economy were dark and deep and not accessible to academics; Stalinist industrialisation had welded a set of incentives into place which clever software could not touch; the system was administered by rent-seeking gangsters; the mathematicians were relying (at two removes) on conventional neoclassical economics to characterise the market processes they were trying to simulate, and the neoclassicists may just be wrong about how capitalism works.

In other words, using this technology would in effect have destroyed the bureaucracy that controlled the planned economy.

In Cybernetic Revolutionaries: Technology and Politics in Allende's Chile (MEDINA, 2014), Eden Medina shows that in Allende's Chile a similar experience was undertaken, but this time it was not the government that killed the attempt, quite the contrary, but the Pinochet coup. Here's a synopsis of the book by Amazon ${ }^{1}$ :

\footnotetext{
${ }^{1}$ Quoted from Amazon.uk
} 
In Cybernetic Revolutionaries, Eden Medina tells the history of two intersecting utopian visions, one political and one technological. The first was Chile's experiment with peaceful socialist change under Salvador Allende; the second was the simultaneous attempt to build a computer system that would manage Chile's economy. Neither vision was fully realized. Allende's government ended with a violent military coup; the system, known as Project Cybersyn, was never completely implemented-but they hold lessons for today about the relationship between technology and politics.

Drawing on extensive archival material and interviews, Medina examines the cybernetic system envisioned by the Chilean government--which was to feature holistic system design, decentralized management, human-computer interaction, a national telex network, near real-time control of the growing industrial sector, and modelling the behaviour of dynamic systems. She also describes, and documents with photographs, the network's Star Trek-like operations room, which featured swivel chairs with armrest control panels, a wall of screens displaying data, and flashing red lights to indicate economic emergencies. Studying project Cybersyn today helps us understand not only the technological ambitions of a government in the midst of political change but also the limitations of the Chilean revolution. This history further shows how human attempts to combine the political and the technological with the goal of creating a more just society can open new technological, intellectual, and political possibilities. Technologies, Medina writes, are historical texts; when we read them we are reading history.

Under the present circumstances, with exponentially growing bottom-up initiatives, open source alternatives and the Internet as a new means of production, this failed experiences would have far more chances of succeeding. Therefore, a progressive government armed with a commons transitional plan might prove a much better alternative. It would undoubtedly face many difficulties in the beginning, but it would at least open the horizon for a better future. And it would certainly enjoy a wave of solidarity throughout the world.

\section{SOURCES}

BAUWENS, Michel. Four Scenarios for the Collaborative Economy. Available in: <https://www.youtube.com/watch?v=KMV4cqRgV6Q>. Accessed in: 21 May 2013.

The high road towards p2p is dying, prepare yourself for the low road. P2P Foundation. Available in: <http://blog.p2pfoundation.net/the-high-road-towards-p2p-isdying-prepare-yourself-for-the-low-road/2010/06/02>. Accessed in: 16 august 2015.

\section{BAUWENS, Michel; LIEVENS, Jean. De wereld redden - met peer-to-peer naar een postkapitalistische samenleving. Houtekiet, 2013.}

Sauver le monde: vers une économie post-capitaliste avec le peer-to-peer. Paris: Les Liens qui libèrent, 2015. 


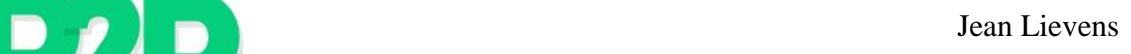

BELGI ̈̈ is 11.900 dollarmillionairs rijker. Available in: <http://www.nieuwsblad.be/cnt/dmf20140618_01145793>. Accessed in: 18 june 2014.

BUEN CONOCER. Available in: 〈http://floksociety.org>. Accessed in: 16 august 2015.

DE MORGEN. Het afscheidsinterview van Dehaene, 2014.

EXAMINATION of Michel Bauwens' P2P Foundation. P2P Foundation, 2015. Available in: <http://p2pfoundation.net/Examination_of_Michel_Bauwens'_P2P_Foundation>. Accessed in: 16 august 2015.

GRAEBER, David. On the Phenomenon of Bullshit Jobs by David Graeber. Strike Magazine. Available in: <http://strikemag.org/bullshit-jobs/>. Accessed in: 16 august 2015.

HARDING, Robin; MCGREGOR, Richard; MULLER, Gabriel. US public investment falls to lowest level since war. Financial Times, 3 November 2013. Available in: <http://www.ft.com/cms/s/0/f0e71a16-4487-11e3-a751-00144feabdc0.html\#slide0>. Accessed in: 16 august 2015.

MEDINA, Eden. Cybernetic Revolutionaries: Technology and Politics in Allende's Chile. Massachusetts: MIT Press, 2014.

NASA report on Global Climate Change. Available in: <http://climate.nasa.gov/scientific -consensus>. Accessed in: 16 august 2015.

RIFKIN, Jeremy. The End of Work: The Decline of the Global Labor Force and the Dawn of the Post-Market Era. New York: Tarcher, 1996.

. The Third Industrial Revolution: How Lateral Power is Transforming Energy, the Economy, and the World Paperback. Palgrave Macmillan, 2013.

The Zero Marginal Cost Society: The Internet of Things, the Collaborative Commons, and the Eclipse of Capitalism, Palgrave Macmillan, 2014.

ROBB, John. Resilient Communities and Scale Invariance. Availabel in: <http://globalguerrillas.typepad.com/globalguerrillas/2009/04/resilient-communities-andscale-invariance.html>. Accessed in: 16 august 2015.

The Decline of the West, 8 May 2010. Availabel in: <http://globalguerrillas.typepad.com/globalguerrillas/2010/05/the-decline-of-thewest.html>. Accessed in: 16 august 2015.

ROBERT, Michael. Grexit, de long and the wages of sinn. Available in: $<$ https://thenextrecession.wordpress.com/2015/07/26/grexit-de-long-and-the-wages-ofsinn/>. Accessed in: 26 July 2015. 
RUNDLE, Michael. Hole in the ozone layer 'solved' reports Nasa. Wired May, 7 May 2015. Available in: <http://www.wired.co.uk/news/archive/2015-05/07/ozone-hole>. Accessed in: 16 august 2015.

SAMSON, Kevin. The Privatization of Water: Nestlé Denies that Water is a Fundamental Human Right. 27 June 2013. Available in: <http://www.globalresearch.ca/the-privatisationof-water-nestle-denies-that-water-is-a-fundamental-human-right/5332238> . Accessed in: 16 august 2015.

SPUFFORD, Francis. Red plenty: lessons from the Soviet dream. The Guardian 7 August 2010. Availabel in: <http://www.theguardian.com/books/2010/aug/07/red-plenty-francisspufford-ussr>. Accessed in: 16 august 2015.

SPUFFORD, Francis; PLENTY, Red. Faber \& Faber, Main edition. 7 July 2011. Availabel in: <http://www.faber.co.uk/9780571225248-red-plenty.html>. Accessed in: 16 august 2015 .

STONE, Brad. Google and Facebook's Race to Bring the Web to the Developing World. Bloomberg Business, 3 March 2015. Available in: <http://www.bloomberg.com/ news/articles/2015-03-03/google-and-facebook-s-race-to-bring-the-web-to-the-developingworld>. Accessed in: 16 august 2015.

PIKETTY, Thomas. Capital in the Twenty-First Century. Cambridge: Harvard University Press, 2014.

US Senate refuses to accept humanity's role in global climate change, again. The Guardian, 22 January 2015. Available in: <http://www.theguardian.com/environment/ 2015/jan/22/us-senate-man-climate-change-global-warming-hoax $>$. Accessed in: 16 august 2015. 